\title{
Morphological Variation and Species Distribution of Baccaurea dulcis (Jack) Müll. Arg. in West Java, Indonesia
}

\author{
Reni Lestari ${ }^{1}$ \\ ${ }^{1}$ Center for Plant Conservation Bogor Botanical Gardens, Indonesian Institute of Sciences, Indonesia \\ Correspondence: Reni Lestari, Center for Plant Conservation Bogor Botanical Gardens, Indonesian Institute of \\ Sciences, Jl. Ir. H. Djuanda 13, Bogor, West Java, Indonesia. E-mail: reni_naa@yahoo.com
}

Received: October 7, 2013 Accepted: October 18, 2013 Online Published: November 11, 2013

doi:10.5539/ijb.v6n1p17

URL: http://dx.doi.org/10.5539/ijb.v6n1p17

\begin{abstract}
Baccaurea dulcis is an underutilized plant, primarily grown for its fruit, distributed and cultivated only in Sumatra, Borneo and western part of Java Island, and its population is under threat. On the other hand, very few studies have been carried out of this species. The objective of this study was to estimate population distribution and ecology of Baccaurea dulcis in West Java, characterize plant morphological characters and correlate plant habitat of $B$. dulcis and the plant and fruit. In West Java $B$. dulcis is only distributed in the sub district Taman Sari of Bogor and sub district Cijeruk of Sukabumi. Even though the species in West Java has a restricted distribution, its morphological characters is quite varied, including size and nature of tree; color and texture of the bark; size and shape of leaves and fruits; color of fruit peel and pulp; and the size, shape and color of seeds. The species grow well in the low land $(250 \mathrm{~m}-610 \mathrm{~m}$ above sea level) of tropical region at neutral soil $\mathrm{pH}$ of regosol or latosol soil type and smooth rather coarse soil texture at land slope from $0 \%$ until $45 \%$. Using 32 variables of trunk, leaf, fruit and seed, all samples could be clustered into 6 groups with the proportion correct 0.903 and with specific fruit characters in each group. There were some significant positive and negative correlations found between habitat and fruit characters and among tree and fruit variables.
\end{abstract}

Keywords: Baccaurea dulcis, underutilized tropical fruit, West Java, characterization, variation, clustering, correlation

\section{Introduction}

Baccaurea dulcis (Jack) Müll.Arg. is a dioecious plant species belonging to the family Phyllantaceae (previously under Euphorbiaceae) (Haegens, 2000; Wurdack et al., 2004). Its common names are ketupa (English), cupa, tupa, kapul, menteng negri, menteng besar (Indonesian), tjupa, tupa (Malaysian). This species is distributed and cultivated only in Sumatra and western part of Java Island (Uji, 1992).

This species is primarily grown for its fruit. It is propagated mainly by seeds, but rarely by vegetative means. The tree produces fruits in high quantities and the fruits are usually taste sour or fairly sweet. The fruits can be pickled and used in stew or fermented to make wine (Uji, 1992; Munawaroh, 2001). The leaf of B. dulcis is boiled and the resulted decoction is used to treat stomachache during menstruation (Munawaroh, 2001). The tree trunk is used in construction (Heyne, 1987). The fruits of B. dulcis are rounded, with a diameter of $3.5-4 \mathrm{~cm}$ and brownish yellow in color. The edible arils are cream, white or reddish in color. Nutrition of fresh pulp of $B$. dulcis per $100 \mathrm{~g}$ were $82.3 \mathrm{~g}$ water, $0.4 \mathrm{~g}$ protein, $7.5 \mathrm{~g}$ saccharosa, $0.2 \mathrm{~g}$ fibers, $0.5 \mathrm{~g}$ ash, $5 \mathrm{mg}$ vitamin $\mathrm{C}, 0 \mathrm{~g}$ vitamin B1 and B2 (Uji, 1992).

In general, the species is underutilized and used only locally. The species is usually grown in the home-yard and the fruits are usually self-consumed and rarely sold in local markets in West Java. Even though, the species is relatively known by the local people, but until now the distribution in West Java is only in very small areas. There is no information about the cultivation of the plant, reproductive period, growth pattern, pest and diseases and production and harvest of the species (Uji, 1992). Vegetative propagation of the species by shoot tip grafting could be applied, which almost $100 \%$ success rate, whereas the airlayering propagation technique resulted only $27.5 \%-40 \%$ of rooted shoot (Lestari, 2009, 2010). The risk of extinction of a fruit species is higher because there are not many people interested in the fruits and the fruits availability in the market is rare (Subekti et al., 2005). Field trips were conducted in West Java to study the species. 
The aims of the study were (1) to find out the distribution of the species Baccaurea dulcis in West Java and to characterize the plants and fruits based on the morphology and qualitative parameter such as color and texture, (2) to find out the variation and clustering B. dulcis plants and fruits in West Java, and (3) to find out the correlation between the characters of the plants and fruits, and the plant's habitat.

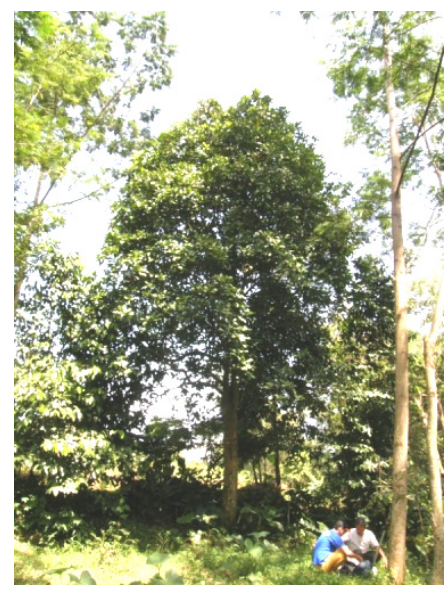

A

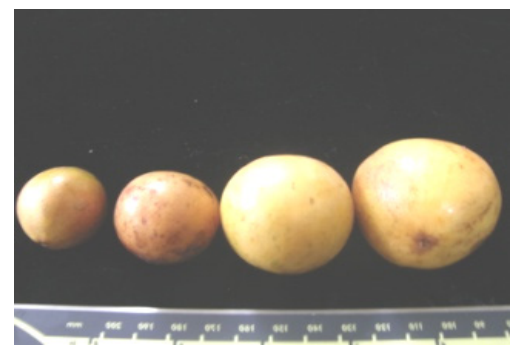

B

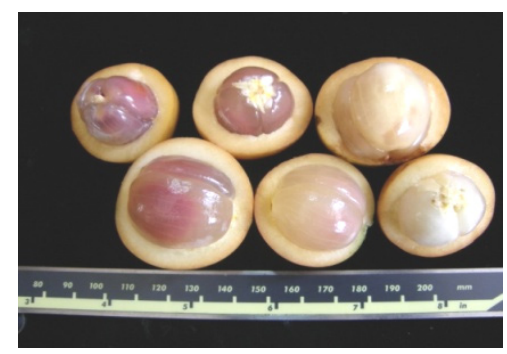

C

Figure 1. A. Baccaurea dulcis plant; B. and C. B. dulcis fruits

\section{Materials and Methods}

\subsection{Distribution, Characterization and Variation of Plant and Fruit}

Field trips, and ecological observations of $B$. dulcis focused on trees, fruits and their habitat and interviews with the farmers were conducted two days a week during the harvest period, starting from February until April 2008 mostly in Bogor, Cianjur, Sukabumi, Tangerang, Depok, Bekasi and Purwakarta of West Java, Indonesia (Figure 2).

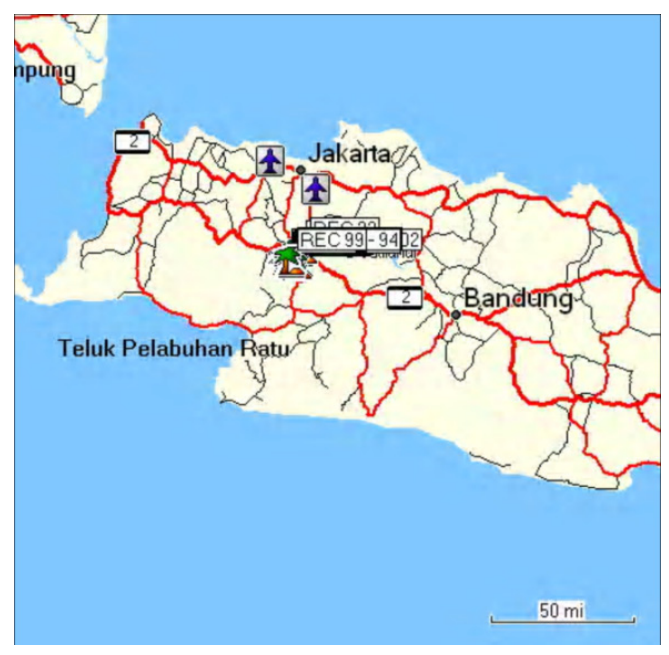

Figure 2. Study site in West Java of Indonesia

The distribution of a total of 103 fruiting plants was recorded. The habitat of the plants and the variables of the tree and fruit were documented. The observation of the plant habitat included location of plant growth, altitude, longitude and altitude, air temperature, relative humidity, slope, light intensity, soil $\mathrm{pH}$, soil relative humidity, soil type and soil texture/drainage. The distribution and habitat of the plant was also examined from the herbaria at the Bogor Herbarium (BO). Detail character variables of tree and fruit observed could be seen in Table 1. 
As many as 30 fruits randomly were harvested from every plant observed, the minimum and maximum length and width of fruit and seed were measured. The fruits were grouped into 3 and each group of fruits was weighed to calculate the average fruit weight. Using kitchen knife, all of those fruits were peeled and then observed for the easiness to peel, the minimum and maximum amount of the pulp segment and the seed weight. The average of each of those parameters was calculated. The thickness of fruit peel and pulp, and soluble solid content of pulp were measured from 3 samples of fruits randomly. Some qualitative parameters were observed during the field trips and the result of the observation was ranked for the data analysis (Table 2).

Table 1. The Variables observed of trees and fruits of B. dulcis in West Java

\begin{tabular}{llll}
\hline No & Variables & No & Variables \\
\hline 1 & Tree height & 17 & Fruit peel color \\
2 & Trunk diameter & 18 & Easiness to peel the fruit \\
3 & Canopy width & 19 & Thickness of fruit peel \\
4 & Canopy condition (sparse/dense) & 20 & Peel weight per fruit \\
5 & Lowest branch height & 21 & Pulp color \\
6 & Bark color & 22 & The number of fruit segment \\
7 & Bark texture & 23 & Soluble solid content of pulp \\
8 & Leaf shape & 24 & Seed shape \\
9 & Leaf length & 25 & Seed length \\
10 & Leaf width & 26 & Seed width \\
11 & The Ratio of maximum leaf length/leaf width & 27 & Ratio of the longest seed length/ seed width \\
12 & Fruit shape & 28 & Seed weight \\
13 & Fruit length & 29 & Percentage of peel weight per fruit \\
14 & Fruit width & 30 & Percentage of pulp weight per fruit \\
15 & The ratio of maximum fruit length/ fruit width & 31 & Percentage of seed weight per fruit \\
16 & Fruit weight & 32 & Seed color \\
\hline
\end{tabular}

Table 2. Qualitative parameters and rank of qualitative number of the observation of $B$. dulcis trees, fruits and seeds in West Java

\begin{tabular}{|c|c|c|}
\hline No & Qualitative parameter & Rank of Qualitative Number and Information \\
\hline 1 & Canopy condition & (1) Dense, (2) Medium dense, (3) Sparse \\
\hline 2 & Bark color & $\begin{array}{l}\text { (1) Light brown/cream, (2) Medium brown, (3) Grey - medium brown, (4) Grey, } \\
\text { (5) Browned - grey, (6) Grey, yellowed - medium brown, (7) Grey - dark brown, } \\
\text { (8) Dark brown, (9) Browned - black }\end{array}$ \\
\hline 3 & Bark texture & $\begin{array}{l}\text { (1) Smooth, (2) Flaky - smooth, (3) Lenticelate, (4) Flaky - lenticelate, (5) Lump - } \\
\text { flaky, (6) Flaky, (7) Flaky - fissured, (8) Flaky - rectangular }\end{array}$ \\
\hline 4 & Fruit peel color & $\begin{array}{l}\text { (1)Yellow, (2) Light orange/Yellowish orange, (3) Orange/ dark orange, (4) } \\
\text { Reddish yellowish - orange }\end{array}$ \\
\hline 5 & Easiness to peel the fruit & (1) Easy, (2) Medium, (3) Difficult \\
\hline 6 & Fruit pulp color & $\begin{array}{l}\text { (1) White, (2) Transparent - white, (3) Cream, (4) Pink, transparent - cream, (5) } \\
\text { Pink, white - transparent, (6) Cream - transparent, (7) Pink - transparent, (8) } \\
\text { Pinked/purpled lines - cream/white }\end{array}$ \\
\hline 7 & Seed color & $\begin{array}{l}\text { (1) Light brown, (2) Pink - light brown, (3) Brown, (4) Pink - brown, (5) } \\
\text { Purplish - brown, (6) Light brown - Pink, (7) Pink }\end{array}$ \\
\hline
\end{tabular}




\subsection{Measurement Equipments}

The equipment used during the observation were GPS Garmin (latitude), Termohygrometer Haar-Synth-Hygro, Germany (air temperature and relative humidity), Soil tester TEW Type 36, Demetra, Japan (soil pH and relative humidity), Clinometer, Suunto PM-5/360, Finland (slope), Light meter, LX-101 A, Lutron, Taiwan (light intensity), Altimeter (altitude). Other equipment used are to measure the tree height (BL 6, Carl Leiss, Berlin, Germany), the diameter of trunk, fruit and seed (diameter tape $20 \mathrm{~m}$ x $5 \mathrm{~m}$, Tool No. D-5M, YAMAYO, Japan), canopy width (Tape measure, $50 \mathrm{~m}$ ), the width of fruit and seed (Digital caliper, $200 \mathrm{~mm}$, Mitutoyo CO., Japan), the fruit and seed weight (Balance, capacity $2 \mathrm{~kg}$ ), Soluble solid content (Digital refractometer, Palette Series PR $101 \alpha$, ATAGO CO., LTD, Japan)

\subsection{Statistical Analysis of the Data}

As many as 32 tree and fruit variables observed from 103 numbers of $B$. dulcis in West Java were clustered to find out the groups based on the similarity characters using the MINITAB program version 14 . The variables chosen were those that are not influenced by the age of the tree observed. Those variables were bark color and texture, maximum and minimum of leaf length and width, ratio of maximum leaf length and width, maximum and minimum of fruit length and width, ratio of maximum fruit length and width, fruit weight, peel color, easiness to peel the fruit, maximum and minimum of thickness of peel, peel weight, pulp color, maximum and minimum number of fruit segment, soluble solid content of pulp, maximum and minimum of seed length and width, ratio maximum seed length and width, seed weight, percentage of peel, pulp and seed weight per fruit and seed color. The qualitative parameters and detailed rank of qualitative number and information of the observation of B. dulcis trees, fruits and seeds for clustering are shown in Table 2.

The same variables were also tested by Linier Discriminant Analysis using the MINITAB program version 14 to find distinctive characteristic of each group. The correlations between the tree and fruit variables and its habitat as well as among the trees and fruits variables were tested using the statistical MINITAB program version 14 .

\section{Results and Discussion}

\subsection{Distribution, Characterization and Variation of Baccaurea dulcis in West Java}

From the study of herbaria, it was known that Baccaurea dulcis is distributed in Sumatra, Borneo and Western part of Java. In Sumatra, the species is distributed in Palembang, Lampung, Riau, Payakumbu, Bangka, Siberut and Jambi, whereas in Borneo, the species was spread in Ketapang, Gunung Palung National Park, Sarawak, and West Samarinda. In West Java, the species was found in Batutulis and Kotabatu of Bogor. Most of the herbaria observed were collected by Dutch explorers long time ago, before or in the early to mid 1900's. Therefore, the distribution of the species at present including in Sumatra and Borneo may have changed. Indeed, increasing human population and land-use intensification resulted in the loss habitats and increasing species extinction rates. Several strong climate oscillation and disaster could affect vegetation shape and species distribution (Ounsavi \& Sokpon, 2010). Whereas in West Java at the moment, there is no B. dulcis plant found in Batutulis and Kotabatu anymore.

From the field trips and observation in West Java, it is known that besides as collection in the botanical garden, the distribution of B. dulcis in West Java was only in sub districts Taman Sari of Bogor district and Cijeruk of Sukabumi district. The result showed that the occurrence of the species in West Java is only in very restricted areas. According to people in the local areas, the species used to abundant in the past, including in other villages of Bogor district. However, people usually cut the trees and used the trunk for many purposes such as material for building/house and equipments. On the other hand, the species is rarely planted. The plants usually grew from seeds that drop at the surrounding of the mother plants. The risk of extinction of the plant species is high because there were not many people interested in the fruits. Therefore, conservation and development of species to become more commercialized are needed.

The results of the characterization of trees and fruits of B. dulcis and plant habitat can be seen in Table 3 . The plants were only found in the home-yard, small garden or botanical garden at an altitude range of $250 \mathrm{~m}-610 \mathrm{~m}$ above sea level, this means that the species could grow well and be planted in relatively low lying areas. From Table 3, it is also known that the trees grow well in the tropical region at neutral soil $\mathrm{pH}$ of regosol or latosol soil type and smooth until rather coarse soil texture at land slope from $0 \%$ until $45 \%$. From the study of herbaria, it is also known that the species grew well in gully river bank, in hillside of primary forest, swampy places, riverside and also cultivated at "kampoeng" or remote village. The plants could grow at the location until $1100 \mathrm{~m}$ above sea level at sandyloam soil and swampy places.

From the observation and measurement results, the morphological characters of B. dulcis were various (Table 3). 
Those included nature of tree, color and texture of the bark, size and shape of leaves and fruits, color of fruit peel and pulp and the size, shape and color of seeds. It is clear from the study that there is considerable phenotypic variation in almost every parameter observed and measured. Similar to another study on the variation of fruit of Irvingia gabonensis, an indigenous fruit tree of west and central Africa, there were significant variation in fruit, nut and kernel size and weight (Leakey et al., 2000). Differences were also identified in shell weight and brittleness, fruit taste, fibrousity and pulp color (Leakey et al., 2000). Salisbury (1942) mentioned that seed size varies tremendously among plant species and was investigated early as a life-history trait of obvious importance. Variation in seed size and weight of Desmodium paniculatum (Leguminosae) was also reported in a population in two locations in North Carolina, USA, which caused by environmental conditions and nutrient supply (Wulff, 1986). The result of other study on population of a single seeded fruit Ocota tenera (Lauraceae) from Monteverde, Costa Rica showed that the fruits that vary from 1.4 to $2.4 \mathrm{~cm}$ and much variation occurred within individual trees (Wheelwright, 1993). The relative size of fruits produced by different trees remained generally constant over an 11-year period despite slight differences between years in the average size of fruits produced by a given tree (Wheelwright, 1993)

Table 3. Character and variation of B.dulcis trees and fruits in West Java and the plant habitat

\begin{tabular}{|c|c|c|}
\hline No & Data Recorded & Measurement/Description \\
\hline \multicolumn{3}{|c|}{ Habitat } \\
\hline 1 & Location of the plant & Homeyard, small people's garden, Botanical garden \\
\hline 2 & Altitude & $320-610 \mathrm{~m}$ above sea level \\
\hline \multirow[t]{2}{*}{3} & Longitude and & $06^{\circ} 34^{\prime} 49.7^{\prime \prime}-06^{\circ} 40^{\prime} 06.9^{\prime \prime}$ and \\
\hline & Latitude & $106^{\circ} 43^{\prime} 55,9^{\prime \prime}-106^{\circ} 49^{\prime} 25,0^{\prime \prime}$ \\
\hline 4 & Air temperature & $18{ }^{\circ} \mathrm{C}-33{ }^{\circ} \mathrm{C}$ \\
\hline 5 & Relative humidity & $59 \%-100 \%$ \\
\hline 6 & Slope & $0 \%-45 \%$ \\
\hline 7 & Light intensity & $341-299,000 \operatorname{lux}$ \\
\hline 8 & Soil pH & $5.8-7$ \\
\hline 9 & Soil relative humidity & $17 \%-90 \%$ \\
\hline 10 & Soil type & Brown regosol and red-brown latosol \\
\hline 11 & Soil texture & Smooth-rather coarse \\
\hline \multicolumn{3}{|c|}{ Morphology of Tree and Fruit Measurement/Description } \\
\hline 12 & Tree height & $4.5-21 \mathrm{~m}$ \\
\hline 13 & Trunk diameter & $10.5 \mathrm{~cm}-80.5 \mathrm{~cm}$ \\
\hline 14 & Canopy width & $3.2 \mathrm{~m}-13.2 \mathrm{~m}$ \\
\hline 15 & Canopy condition & Sparse - Medium - Dense \\
\hline 16 & Lowest branch height & $0.55 \mathrm{~m}-7.0 \mathrm{~m}$ \\
\hline 17 & Bark color & $\begin{array}{l}\text { Light brown/cream, Medium brown, Grey-medium brown, Grey, } \\
\text { Browned-grey, Grey, yellowed-medium brown, Grey-dark brown, } \\
\text { Dark brown, Browned-black }\end{array}$ \\
\hline 18 & Bark texture & $\begin{array}{l}\text { Smooth, Flaky-smooth, Lenticelate, Flaky-lenticelate, Lump-flaky, } \\
\text { Flaky, Flaky-fissured, Flaky-rectangular }\end{array}$ \\
\hline 19 & Leaves shape & Obovate, lanceolate \\
\hline 20 & leaf length & $7.7 \mathrm{~cm}-30 \mathrm{~cm}$ \\
\hline 21 & Leaf width & $3.1 \mathrm{~cm}-14.9 \mathrm{~cm}$ \\
\hline 22 & $\begin{array}{l}\text { Ratio maximum leaf length/maximum } \\
\text { leaf width }\end{array}$ & 2.01 \\
\hline
\end{tabular}




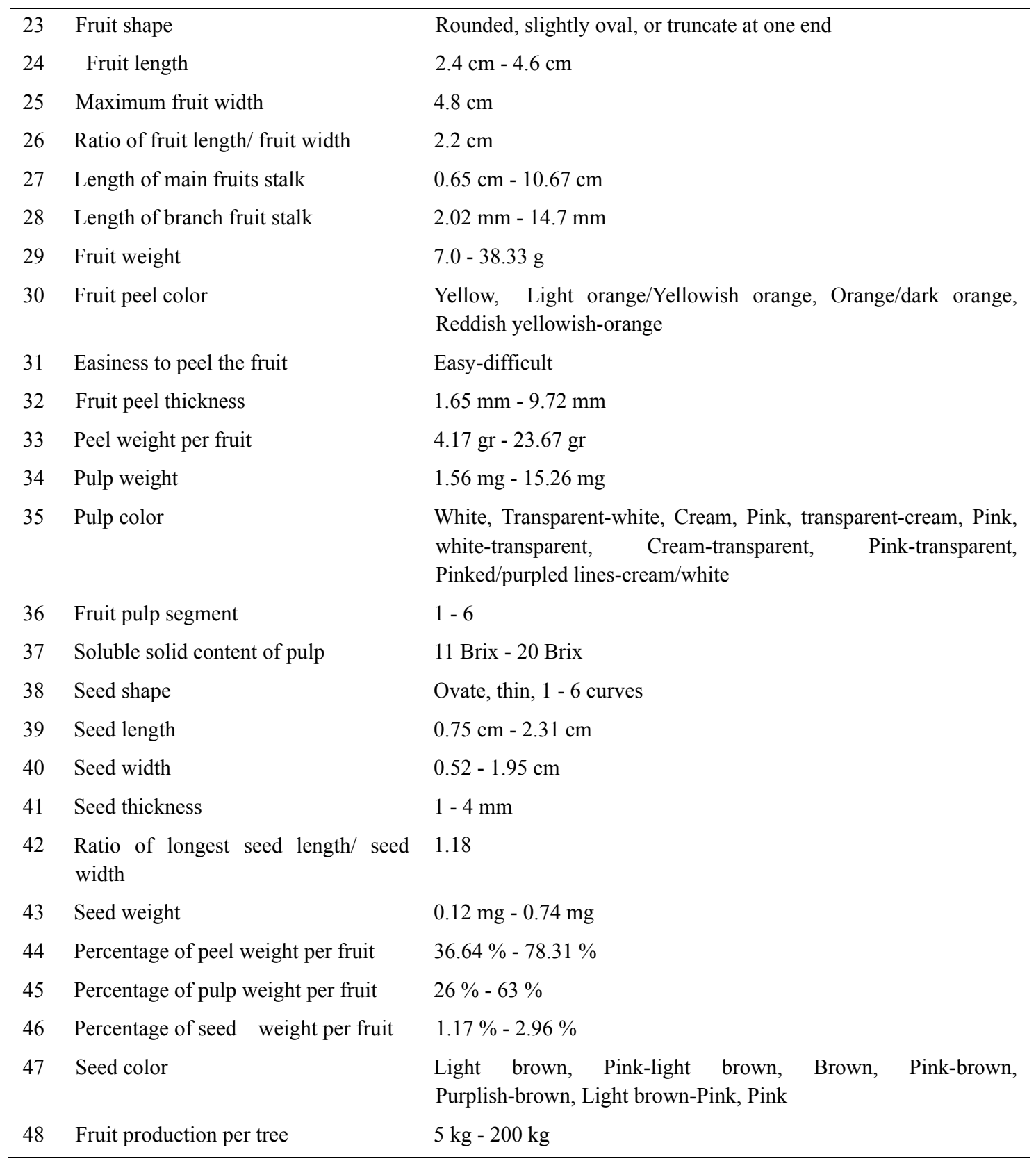

\subsection{Clustering of Baccaurea dulcis Variation in West Java}

Using 32 variables of trunk, leaf, fruit and seed, all samples could be clustered into 6 groups with the proportion correct 0.903 (Figure 4, Table 5). As can be seen at Table 4, the characters that belong to group 1 were small and light fruit, light fruit peel, small seed and sweeter fruit taste, whereas those of group 2 were fruit pulp color white/transparent, small seed, low portion of fruit pulp and high portion of fruit peel. Group 3 belongs to the tree and fruit of $B$. dulcis with the characters of big and heavier fruit, high portion of fruit pulp, more heavy seed, more segment of fruit pulp (Table 4). The characters of group 4 were thin and light fruit peel, more segment of fruit pulp, high portion of fruit pulp, low portion of fruit peel, color of fruit pulp reddish/purple. Group 5 were characterized by big and more heavy fruit, thick and more heavy fruit peel, fruit pulp color white/transparent, big seed and high portion of fruit pulp, whereas group 6 were characterized by light fruit, sour taste, small seed, color of fruit pulp reddish or purple (Table 4). Another study on the variation of pomelo (Citrus grandis) in Nepal found that from the multivariate analysis of the data produced five discrete groups, which differed significantly in fruit shape and size, pulp, juice, total soluble solids and acid content, seed number, leaf shape and size (Paudyal \& Haq, 2008). 


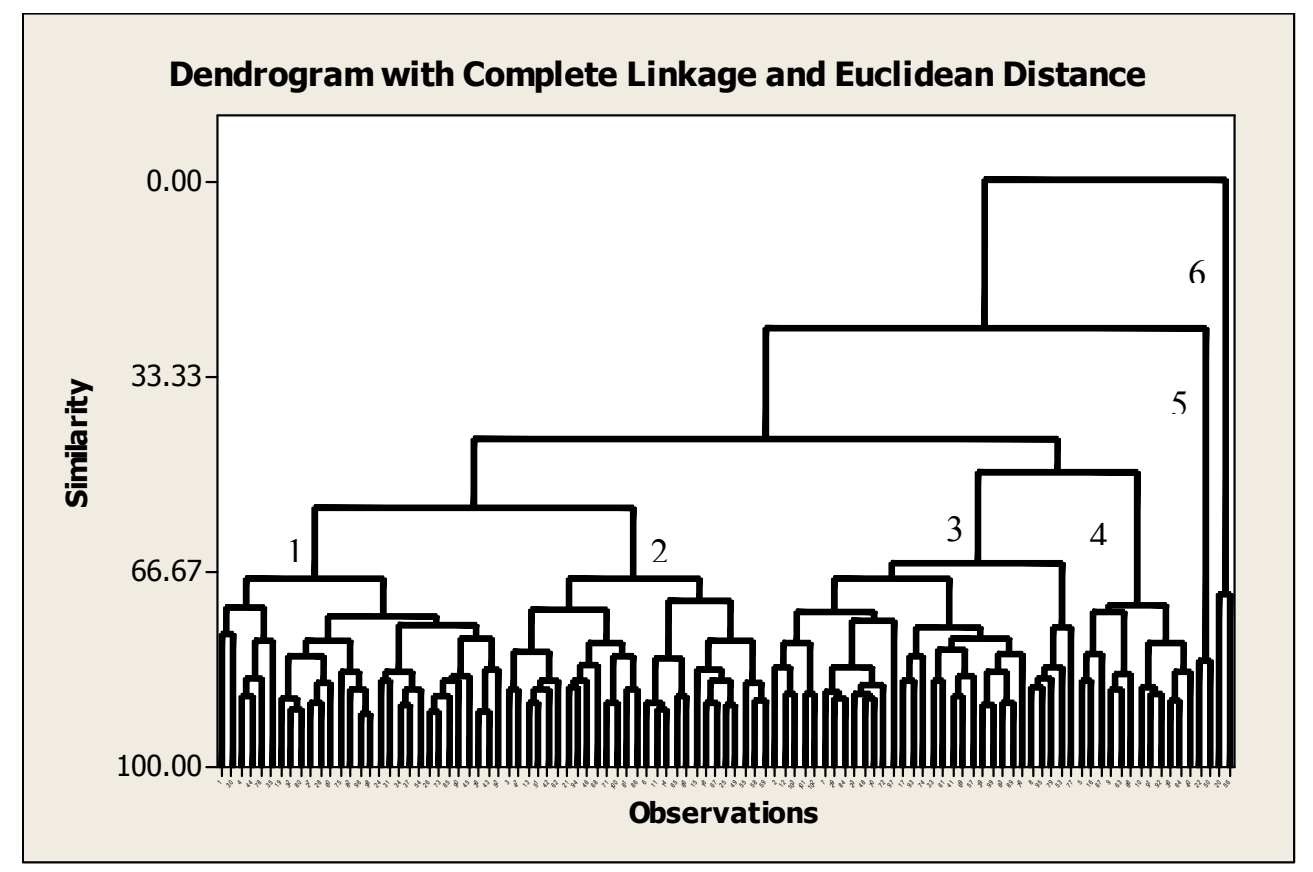

Figure 3. Dendrogram of $B$. dulcis in West Java based on the similarity variables

Table 4. Average value of characteristic component of 6 groups B. dulcis in West Java

\begin{tabular}{cccccccc}
\hline Characteristic variable & Group 1 & Group 2 & Group 3 & Group 4 & Group 5 & Group 6 & Population mean \\
\hline Bark color & 2.90 & 3.09 & 3.73 & 1.60 & 4.50 & 4.00 & 3.32 \\
Bark texture & 4.79 & 4.74 & 5.31 & 5.60 & 5.25 & 5.00 & 5.01 \\
Leaf length & 21.75 & 23.09 & 22.78 & 21.58 & 23.46 & 20.23 & 22.49 \\
Leaf width & 10.68 & 10.68 & 10.65 & 9.80 & 10.90 & 9.65 & 10.62 \\
Fruit size & 35.94 & 37.12 & 39.60 & 38.26 & 41.87 & 36.80 & 38.01 \\
Fruit weight & 18.44 & 21.18 & 26.44 & 22.95 & 31.96 & 20.01 & 23.03 \\
Peel color & 2.39 & 2.82 & 2.55 & 2.40 & 2.75 & 2.75 & 2.60 \\
Peel thickness & 6.50 & 6.94 & 6.27 & 5.29 & 7.87 & 6.39 & 6.65 \\
Peel percentage & 58.25 & 65.92 & 54.39 & 46.81 & 62.23 & 59.9 & 59.26 \\
Pulp percentage & 39.84 & 32.33 & 43.85 & 51.45 & 36.27 & 38.20 & 38.97 \\
Minimum pulp segment & 1.7 & 1.7 & 2.0 & 2.4 & 1.8 & 1.8 & 1.8 \\
Maximum pulp segment & 3.5 & 3.4 & 3.7 & 3.6 & 3.3 & 3.3 & 3.5 \\
Pulp color & 3.03 & 2.96 & 3.86 & 3.80 & 2.75 & 4.25 & 3.27 \\
SSC* & 16.51 & 15.55 & 15.82 & 15.72 & 15.69 & 14.69 & 15.88 \\
Seed length & 16.9 & 17.0 & 18.0 & 18.1 & 18.6 & 17.0 & 17.5 \\
Seed width & 12.6 & 13.0 & 14.1 & 13.9 & 14.1 & 13.6 & 13.4 \\
\hline
\end{tabular}

*SCC $=$ Soluble solid content of fruit pulp. 
Table 5. Results of test of correctness based on discriminant analysis for summary of classification

\begin{tabular}{ccccccc}
\hline & \multicolumn{7}{c}{ True Group } \\
\cline { 2 - 7 } Put into Group & 1 & 2 & 3 & 4 & 5 & 6 \\
\hline 1 & 28 & 2 & 2 & 0 & 0 & 0 \\
2 & 0 & 23 & 0 & 0 & 0 & 1 \\
3 & 0 & 0 & 23 & 0 & 1 & 0 \\
4 & 0 & 0 & 1 & 5 & 0 & 0 \\
5 & 0 & 0 & 0 & 0 & 11 & 0 \\
6 & 1 & 2 & 0 & 0 & 0 & 3 \\
Total N & 29 & 27 & 26 & 5 & 12 & 4 \\
N correct & 28 & 23 & 23 & 5 & 11 & 3 \\
Proportion & 0.966 & 0.852 & 0.885 & 1.000 & 0.917 & 0.750
\end{tabular}

Note: $\mathrm{N}=103, \mathrm{~N}$ Correct $=93$ and Proportion Correct $=0.903$.

\subsection{Correlations Among Habitat, Plant and Fruit Variables}

The result of the statistical data analysis for significant correlation between plant habitat and variables of tree and fruit could be seen in Table 6. There was one significant positive correlation and nine significant negative correlations known. The positive correlation was between slope and fruit pulp color, whereas significant negative correlation were between altitude and pulp weight; light intensity and pulp soluble solid content (SSC); soil pH and number of pulp segment; soil texture and trunk diameter, canopy width, pulp color, pulp weight, peel weight portion; drainage and number of pulp segment (Table 6).

This findings could indicate that higher slope the plant grow, the pulp color of the fruit tend to be pink or purple. On the other hand, higher the altitude of the plant position could correlate with less weight of the fruit pulp; more light intensity could correlate with less pulp SSC. Light intensity could have an effect on the pulp color and pulp SSC, while air temperature could affect the weight of fruit pulp.

The other significant negative correlation indicated that higher soil $\mathrm{pH}$ correlates with less pulp segment; more coarse the soil texture correlates with less trunk diameter, less canopy width, more white/transparent pulp color, less pulp weight, less peel portion; higher soil drainage correlates with less number of pulp segment. The soil texture and soil drainage could correlate with the soil fertility condition, which then could affect the size of the plant. Other study on pomelo (Citrus grandis) in Nepal found that yield related characters, such as fruit weight had positively correlated with tree size and soil fertility level, but none of these factors were correlated with fruit quality, such as percent of pulp and pulp SSC (Paudyal \& Haq, 2008)

Table 6. Significant correlation between plant habitat and variables of Baccaurea dulcis

\begin{tabular}{ccccccc}
\hline Plant/Habitat & Altitude & Slope & $\begin{array}{c}\text { Light } \\
\text { intensity }\end{array}$ & Soil pH & $\begin{array}{c}\text { Soil } \\
\text { Texture }\end{array}$ & Drainage \\
\hline Trunk Diameter & -0.094 & 0.077 & 0.073 & 0.123 & $-0.199^{*}$ & -0.098 \\
Canopy width & 0.011 & 0.029 & -0.070 & -0.081 & $-0.200^{*}$ & -0.024 \\
Pulp color & -0.213 & $0.226^{*}$ & -0.056 & -0.166 & $-0.205^{*}$ & -0.137 \\
Minimum number of pulp segment & -0.047 & 0.070 & -0.133 & $-0.223^{*}$ & 0.180 & 0.006 \\
Maximum number of pulp segment & 0.120 & -0.168 & 0.079 & 0.110 & -0.004 & $-0.194^{*}$ \\
Pulp soluble solid content & 0.106 & 0.135 & $-0.208^{*}$ & 0.047 & 0.166 & 0.086 \\
Pulp weight & $-0.246^{*}$ & 0.007 & 0.058 & -0.006 & $-0.261^{*}$ & -0.154 \\
Peel weight portion & -0.155 & 0.016 & -0.071 & 0.093 & $-0.294^{*}$ & -0.063 \\
\hline
\end{tabular}

* Significant correlation. 
It could be seen at Table 7 that there was significant correlation among the variable of $B$. dulcis trees and fruits in West Java. Significant positive correlations were found between (1) Canopy diameter and trunk width; (2) Maximum fruit width and fruit weight, pulp thickness, peel color, peel thickness, pulp soluble solid content (SSC), seed length, seed width, seed weight; (3) Maximum fruit length and seed weight per fruit; (4) Fruit weight and peel color, peel thickness, pulp SSC, seed length, seed width, seed weight; (5) Pulp thickness and peel weight, pulp SSC, seed width, seed weight; (6) Easiness to peel and peel color; (7) Peel color and peel thickness; (8) Peel thickness and pulp SSC, seed length, seed width, seed weight, pulp portion; (9) Pulp color and seed weight, pulp weight; (10) Pulp SSC and seed width; (11) Maximum seed length and maximum seed width, seed weight; (12) Maximum seed width and seed weight.

The results of positive significant correlation among the variable of $B$. dulcis trees and fruits in West Java (Table 7) indicate that the trunk width is in accordance with canopy diameter; the fruit size is in accordance with size of seed, peel and pulp; more difficult to peel the fruit correlates with more red/orange peel color and more thick the peel.

On the other hand, the significant negative correlation among the variable of $B$. dulcis trees and fruits in West Java (Table 7) were between (1) Peel weight and tree height, trunk diameter, peel color, pulp color; (2) Pulp thickness and easiness to peel, peel portion; (3) Easiness to peel and pulp color, maximum pulp segment, pulp SSC, maximum seed length, seed weight per fruit, pulp weight per fruit; (4) Peel color and peel weight, pulp weight per fruit, peel portion; (5) Peel thickness and pulp weight, peel portion; (6) Pulp color and pulp SSC; (7) Maximum pulp segment and easiness to peel, pulp SSC, maximum seed width; (8) Seed weight and pulp weight per fruit; (9) Pulp weight per fruit and leaf length, leaf width, easiness to peel, peel color, peel thickness, pulp portion; (10) Peel portion and leaf length, leaf width, fruit length, fruit width, fruit weight, pulp thickness, peel color, peel thickness, seed weight per fruit.

The result of significant negative correlation among the variable of $B$. dulcis trees and fruits in West Java (Table 7) indicates the composition of fruit parts is in accordance; more weight of fruit peel correlate with smaller tree and more dull peel and pulp color; more thick the pulp, more difficult to peel the fruit; more red/purple pulp color less sweet of the pulp; more weight of pulp and peel portion correlates with less size of leaf. Other study regarding fruit variation of Irvingia gabonensis, an indigenous fruit tree of West and Central Africa found that there were very weak relationship between fruit size and weight with nut and kernel size and weight (Leakey et al., 2000).

Table 7. Significant correlation among the variables of Baccaurea dulcis trees and fruits from West Java

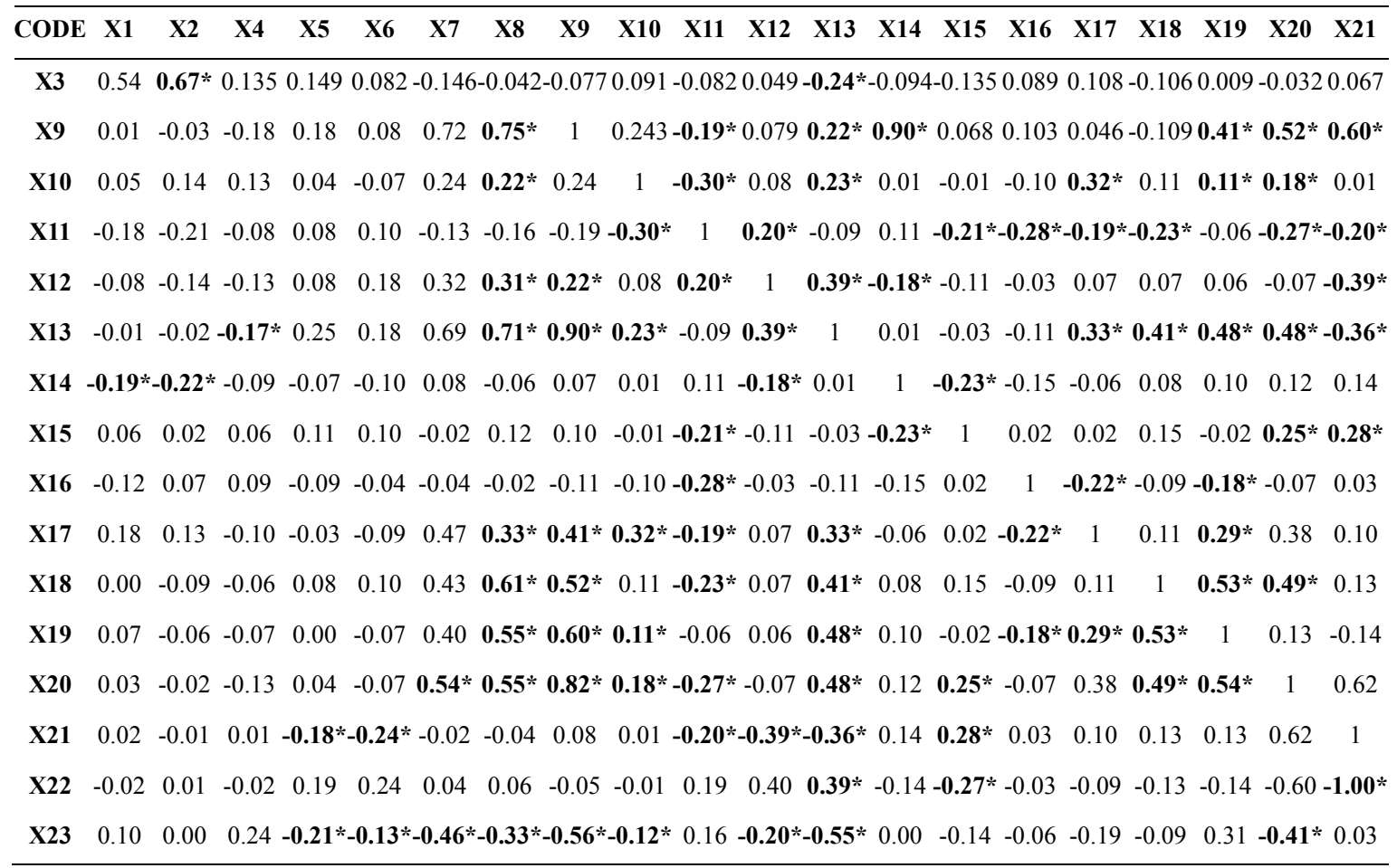


$\mathrm{X} 1=$ Tree height, $\mathrm{X} 2=$ Trunk diameter, $\mathrm{X} 3=$ Canopy width, $\mathrm{X} 4=$ Lowest branch height, $\mathrm{X} 5=$ Maximum leaf length, $\mathrm{X} 6=$ Maximum leaf width, $\mathrm{X} 7=$ Maximum fruit length, $\mathrm{X} 8=$ Maximum fruit width, $\mathrm{X} 9=$ Fruit weight, $\mathrm{X} 10=$ Pulp thickness, $\mathrm{X} 11=$ Easiness to peel, $\mathrm{X} 12=$ Peel color, X13 $=$ Peel thickness, $\mathrm{X} 14=$ Peel weight, $\mathrm{X} 15=$ Pulp color, X16 = Maximum pulp segment, X17 = Pulp SSC, X18 = Maximum seed length, X19= Maximum seed width, $\mathrm{X} 20=$ Seed weight per fruit, X21 = Pulp weight per fruit, X22 = Pulp portion, X23 = Peel portion

\section{Conclusion}

This paper explored the distribution and variation of Baccaurea dulcis (Jack) Müll. Arg. in West Java, Indonesia. The population of the species is under threath. The species has restricted distribution, however the morphological characters were various. Therefore, its conservation is needed. Further study on the influence of genetic and environment aspects to the variation of the species is also important. Moreover, other interesting topic should be gaining high quality of fruits to become more commercialized one.

\section{Acknowledgements}

The presented results are a product of the scientific project carried out with the support of the competitive grant of the Indonesian Institutes of Sciences number 11.9/SK/KPPI/DKP/2008. The author would like to thank Junaedi and Ngatari for technical support.

\section{References}

Haegens, R. (2000). Taxonomy, phylogeny, and biogeography of Baccaurea, Distichirhops, and Nothobaccaurea (Euphorbiaceae). Blumea (Supplement), 12, 1-217.

Heyne, K. (1987). Tumbuhan berguna Indonesia, Jilid II (Translation Edition). Yayasan Sarana Wana Jaya (p. 1247). Jakarta, Indonesia.

Leakey, R. R. B., Fondoun, J. M., Atangana, A., \& Tchoundjeu, Z. (2000). Quantitative descriptors of variation in the fruits and seeds of Irvingia gabonensis. Agrobiodiversity Systems, 50, 47-58. http://dx.doi.org/10.1023/A:1006434902691

Lestari, R. (2009). Propagation of Baccaurea dulcis by airlayering with the addition of plant regulator substance. Proceeding of National Seminar on Flora Conservation to Overcome the Effect of Global Warming (pp. 227-231). "Eka Karya" Bali Botanical Gardens, Indonesian Institute of Sciences, Bali, Indonesia.

Lestari, R., \& Aprilianti, P. (2010). Propagation of "big menteng" (Baccaurea dulcis (Jack) Müll Arg.) by grafting as the efforts of species conservation and development. Proceeding of National Seminar Horticulture on "Research Reorientation for Optimalize Horticultural Product and Value Chain" (pp. 68-75). PERHORTI, Indonesia.

Munawaroh, E. (2001). The potency of Baccaurea spp. as fresh fruit source and its conservation in the Bogor Botanical Gardens. A Day Seminar Proceeding at the National Flora Fauna Day (pp. 81-88). Center for Plant Conservation Bogor Botanical Gardens, Indonesian Institute of Sciences, Bogor.

Ouinsavi, C., \& Sokpon, N. (2010). Morphological variation and ecological structure of Iroko (Milicia excelsa Welw. C. C. Berg) population accross different biogeographical zones in Benin. International Journal of Forestry Research, 1, 1-11. http://dx.doi.org/10.1155/2010/658396

Paudyal, K. P., \& Haq, N. (2008). Variation of pomelo (Citrus grandis (L.) Osbeck) in Nepal and participatory selection of strains for further improvement. Agroforest Syst., 72, 195-204. http://dx.doi.org/10.1007/s10457-007-9088-z

Salisbury, E. J. (1942). The reproductive capacity of plants. G. Bell and Sons. London.

Subekti, A., Yeni, S., Sumaryadi, T., Anggraito, B., \& Ibrahim, T. M. (2005). The examine of domestication and commercialization of fruit species and variety in West Kalimantan. Workshop Proceeding I, Domestication and Commercialization of Horticultural Plant (pp. 23-34). Center for Research and Development of Horticultura, Ministry of Agricultura, Jakarta.

Uji, T. (1992). Baccaurea Lour. In E. W. M. Verheij, \& R. E. Cornel (Eds.), Plant Resources of South East Asia No.2. Edible fruits and nuts (pp. 98-100). Leiden: Backhuys Publishers.

Wheelwright, N. T. (1993). Fruit size in a tropical tree species: variation, preference by birds and heritability. Vegetatio, 107-108, 163-174

Wulff, R. D. (1986). Seed size variation in Desmodium paniculatum, I. Factors affecting seed size. Journal of 
Ecology, 74, 87-97. http://dx.doi.org/10.2307/2260351

Wurdack, K. J., Hoffman, P., Samue, R., de Bruijn, A., van der Bank, M., \& Chase, M. W. (2004). Molecular phylogenetic analysis of Phyllanthaceae (Phyllanthoideae pro parte, Euphorbiaceae sensu lato) using plastid rbcl DNA sequences. American Journal of Botany, 91(11), 1882-1900. http://dx.doi.org/10.3732/ajb.91.11.1882

\section{Supplemental Tables}

Supplemental Table 1. Linear Discriminant Function for Groups

\begin{tabular}{|c|c|c|c|c|c|c|}
\hline \multicolumn{7}{|c|}{ Groups } \\
\hline Variables & 1 & 2 & 3 & 4 & 5 & 6 \\
\hline Constant & -1.919 & -2.066 & -3.039 & -8.559 & -7.571 & -6.580 \\
\hline $\mathrm{C} 42$ & -0.701 & -0.243 & 0.497 & -0.123 & 1.011 & 0.612 \\
\hline $\mathrm{C} 43$ & 0.138 & -0.279 & 0.046 & 1.101 & -0.265 & 0.003 \\
\hline $\mathrm{C} 44$ & -0.261 & 1.509 & -0.645 & -3.309 & -0.209 & 0.669 \\
\hline $\mathrm{C} 45$ & 0.716 & -3.269 & 1.334 & 10.999 & 1.320 & -9.505 \\
\hline $\mathrm{C} 46$ & -0.278 & -0.887 & 0.650 & 1.976 & 0.651 & -0.648 \\
\hline $\mathrm{C} 47$ & -0.952 & 3.241 & -0.800 & -11.732 & -1.707 & 10.016 \\
\hline $\mathrm{C} 48$ & -1.293 & 2.705 & -0.626 & -8.412 & -0.576 & 7.426 \\
\hline $\mathrm{C} 49$ & -1.914 & 0.208 & -0.190 & 2.227 & 3.198 & 1.330 \\
\hline $\mathrm{C} 50$ & -4.671 & -3.609 & 6.154 & 8.508 & 4.450 & -5.760 \\
\hline C51 & 0.394 & -1.632 & 2.082 & 0.206 & -1.029 & -2.545 \\
\hline $\mathrm{C} 52$ & 3.520 & 3.502 & -5.073 & -7.086 & -4.258 & 5.448 \\
\hline $\mathrm{C} 53$ & 3.893 & 2.359 & -3.890 & -7.533 & -4.531 & 4.152 \\
\hline C54 & -7.480 & -4.515 & 18.165 & 23.060 & -10.383 & -31.038 \\
\hline C55 & -0.480 & 0.501 & -0.218 & -0.889 & 0.629 & 0.742 \\
\hline C56 & 0.151 & 0.421 & -0.730 & 0.411 & 0.044 & 0.167 \\
\hline $\mathrm{C} 57$ & 0.271 & -0.621 & 0.065 & 0.541 & 0.443 & -0.203 \\
\hline $\mathrm{C} 58$ & -0.446 & 0.468 & -0.049 & -1.910 & 0.835 & 0.274 \\
\hline C59 & 5.645 & 6.563 & -21.309 & -26.441 & 16.976 & 35.403 \\
\hline C60 & -0.337 & -0.352 & 0.742 & 1.158 & -0.446 & -0.112 \\
\hline C61 & -0.100 & 0.609 & -0.255 & -0.398 & -0.581 & 0.513 \\
\hline C62 & 0.223 & -0.062 & 0.091 & -0.813 & 0.007 & -0.792 \\
\hline C63 & 0.362 & -0.779 & 0.318 & 0.320 & 0.405 & -1.047 \\
\hline C64 & -0.398 & -0.417 & 0.057 & 0.212 & 1.121 & 1.701 \\
\hline C65 & -0.587 & 1.870 & -3.977 & -3.173 & 5.852 & 3.893 \\
\hline C66 & -0.317 & 0.176 & -0.681 & -2.298 & 2.935 & -0.393 \\
\hline C67 & 0.442 & -1.600 & 2.808 & 3.369 & -4.489 & -1.398 \\
\hline C68 & 0.899 & -1.967 & 4.179 & 3.417 & -6.527 & -5.095 \\
\hline C69 & 1.965 & -1.866 & 1.869 & -0.756 & -3.015 & -3.816 \\
\hline $\mathrm{C} 70$ & 40.719 & -21.741 & 12.235 & 1.751 & -60.747 & -47.938 \\
\hline C71 & 38.601 & -21.998 & 18.918 & 8.233 & -67.798 & -61.238 \\
\hline $\mathrm{C} 73$ & -0.658 & 0.215 & 0.307 & 0.604 & 0.063 & 0.383 \\
\hline
\end{tabular}




\section{Copyrights}

Copyright for this article is retained by the author(s), with first publication rights granted to the journal.

This is an open-access article distributed under the terms and conditions of the Creative Commons Attribution license (http://creativecommons.org/licenses/by/3.0/). 